\title{
Low carbohydrate diet-based intervention for obstructive sleep apnea and primary hypothyroidism in an obese Japanese man
}

\author{
Yoshio Tokuchi $^{1 *}$ D, Yayoi Nakamura ${ }^{1}$, Yusuke Munekata ${ }^{2}$ and Fumio Tokuchi ${ }^{1}$
}

\begin{abstract}
Background: Obesity is a major risk factor for obstructive sleep apnea (OSA), and weight loss is necessary in the overall management of obese patients with OSA. However, primary care physicians can provide only limited weight loss with lifestyle interventions, usually reducing a patient's body weight by only $2.5 \mathrm{~kg}$ or less after $6-18$ months.

Case presentation: A 45-year-old Japanese man was referred to our clinic owing to obesity, daytime sleepiness, and snoring during sleep. His weight was $130.7 \mathrm{~kg}$ and his body mass index (BMI) was $41.0 \mathrm{~kg} / \mathrm{m}^{2}$. He underwent polysomnography, which revealed OSA with an apnea-hypopnea index of 71.2 events/h (normal, $<5$ events/h). His laboratory results were as follows: thyroid stimulating hormone, $>500 \mu \mathrm{lU} / \mathrm{mL}$; free triiodothyronine, $1.4 \mathrm{pg} / \mathrm{mL}$; free thyroxine, $<0.15 \mathrm{ng} / \mathrm{dL}$; thyroid peroxidase antibody, $10 \mathrm{IU} / \mathrm{mL}$; thyroglobulin antibody, $>4000 \mathrm{IU} / \mathrm{mL}$; total cholesterol (TC), 335 mg/dL; high-density lipoprotein cholesterol, 45 mg/dL; triglycerides (TGs), 211 mg/dL; low-density lipoprotein cholesterol, $248 \mathrm{mg} / \mathrm{dL}$; fasting blood sugar, $86 \mathrm{mg} / \mathrm{dL}$; and glycated hemoglobin ( $\mathrm{HbA1c}$ ), $6.1 \%$. These results showed that he also had primary hypothyroidism (Hashimoto's disease). Continuous positive airway pressure (CPAP), levothyroxine replacement, and a low-carbohydrate diet (LCD) were initiated. CPAP use and a euthyroid condition induced by $175 \mu \mathrm{g} /$ day levothyroxine allowed the patient to proactively reduce his body weight. After 18 months, the patient achieved a weight reduction of $32.4 \mathrm{~kg}$ ( $25 \%$ of his initial weight) and a BMI reduction of $10.2 \mathrm{~kg} / \mathrm{m}^{2}$, as well as improved laboratory results, including an $\mathrm{HbA} 1 \mathrm{c}$ level of $5.3 \%$, TC level of $194 \mathrm{mg} / \mathrm{dL}$, and TG level of $89 \mathrm{mg} / \mathrm{dL}$.
\end{abstract}

Conclusion: An LCD may be an effective intervention for weight loss in obese Japanese patients with OSA. Further studies are needed to investigate the weight loss effect of an LCD compared with a conventional calorie-restricted diet. Hopefully, this case report will help to improve the management of obese Asian patients with OSA who typically consume a higher amount of carbohydrates.

Keywords: Obstructive sleep apnea, Continuous positive airway pressure, Low-carbohydrate diet, Obesity, Hypothyroidism, Levothyroxine replacement

\section{Background}

Obesity is a major risk factor for obstructive sleep apnea (OSA) [1], and weight loss is necessary in the overall management of obese patients with OSA. However, primary care physicians can provide only limited

\footnotetext{
*Correspondence: yoshio-tokuchi@hokkaido.med.or.jp

1 Tokuchi Naika Clinic, 3-6, Iwamizawa, Hokkaido 068-0023, Japan Full list of author information is available at the end of the article
}

weight loss by medical therapy alone. Previous trials, in which primary care physicians offered lifestyle counseling, achieved a weight loss of only $2.5 \mathrm{~kg}$ or less after 6-18 months $[2,3]$. In addition, intensive medical therapy or enhanced weight loss counseling for patients with obesity has been shown to achieve a mean weight loss of $4.3-5.1 \mathrm{~kg}$ after $2-3$ years $[1,2,4]$. In contrast, continuous positive airway pressure (CPAP) - the standard treatment for OSA-may actually increase the body weight of 
patients [5]. On the other hand, hypothyroidism can be associated with OSA [6], and some symptoms, such as daytime sleepiness, fatigue, and lethargy, overlap for both diseases.

Here, we describe an obese Japanese man with OSA and primary hypothyroidism who was treated with CPAP, levothyroxine replacement, and a low-carbohydrate diet (LCD) and achieved a weight reduction of $32.4 \mathrm{~kg}(25 \%$ of his initial weight) and a body mass index (BMI) reduction of $10.2 \mathrm{~kg} / \mathrm{m}^{2}$ after 18 months.

\section{Case presentation}

In January 2014, a 45-year-old Japanese man was referred to our clinic owing to obesity, daytime sleepiness, and snoring during sleep. His Epworth Sleepiness Scale score was 10 points. He underwent overnight diagnostic polysomnography in February 2014. Upon admission, his height was $178.6 \mathrm{~cm}$, weight was $130.7 \mathrm{~kg}$, abdominal circumference was $122 \mathrm{~cm}$, and BMI was $41.0 \mathrm{~kg} / \mathrm{m}^{2}$. Physical examination showed that the thyroid gland was not palpable. His serum levels of creatine kinase and creatinine were elevated at $1581 \mathrm{U} / \mathrm{L}$ and $1.46 \mathrm{mg} / \mathrm{dL}$, respectively, while his other laboratory results were as follows: aspartate aminotransferase, $57 \mathrm{U} / \mathrm{L}$; alanine aminotransferase, $49 \mathrm{U} / \mathrm{L}$; lactate dehydrogenase, $353 \mathrm{U} / \mathrm{L}$; total cholesterol (TC), $335 \mathrm{mg} / \mathrm{dL}$; high-density lipoprotein cholesterol, $45 \mathrm{mg} / \mathrm{dL}$; triglycerides (TGs), $211 \mathrm{mg} / \mathrm{dL}$; low-density lipoprotein cholesterol, $248 \mathrm{mg} / \mathrm{dL}$; fasting blood sugar, $86 \mathrm{mg} / \mathrm{dL}$; glycated hemoglobin (HbA1c), $6.1 \%$; thyroid-stimulating hormone (TSH), $>500 \mu \mathrm{IU} /$ $\mathrm{mL}$; free triiodothyronine, $1.4 \mathrm{pg} / \mathrm{mL}$; free thyroxine, $<0.15 \mathrm{ng} / \mathrm{dL}$; thyroid peroxidase antibody, $10 \mathrm{IU} /$ $\mathrm{mL}$; and thyroglobulin antibody, $>4000 \mathrm{IU} / \mathrm{mL}$ (Table 1 ). Blood samples were evaluated using routine methods at Sapporo Clinical Laboratory Inc. (Sapporo, Hokkaido, Japan). Based on these results, indicating hypothyroidism and thyroglobulin antibody positivity, the patient was diagnosed with severe primary hypothyroidism (Hashimoto's thyroiditis). His dyslipidemia and impaired glucose tolerance were considered as secondary changes due to primary hypothyroidism and obesity. Because polysomnography showed an apnea-hypopnea index (AHI) of 71.2 events/h (normal, $<5$ events/h) and a minimal $\mathrm{SpO}_{2}$ of $60 \%$, he also was diagnosed with severe OSA associated with autoimmune hypothyroidism. Therefore, in the beginning of March 2014, nasal CPAP (ICON+Auto, auto-adjusting CPAP; Fisher \& Paykel Healthcare Limited, Auckland, New Zealand; minimal pressure, $4.0 \mathrm{cmH}_{2} \mathrm{O}$; maximal pressure, $18.0 \mathrm{cmH}_{2} \mathrm{O}$ ) and low-dose levothyroxine $(12.5 \mu \mathrm{g} /$ day $)$ were initiated. Upon initiation of the CPAP therapy, the patient was informed that he would have to continue with the CPAP therapy unless his body weight decreased sufficiently.
Table 1 Laboratory results of blood samples on admission

\begin{tabular}{|c|c|}
\hline \multicolumn{2}{|l|}{$\mathrm{CBC}$} \\
\hline WBCs & $5500 \times 10^{3} / \mu \mathrm{L}$ \\
\hline RBCs & $452 \times 10^{4} / \mu \mathrm{L}$ \\
\hline $\mathrm{Hgb}$ & $14.1 \mathrm{~g} / \mathrm{dL}$ \\
\hline PLTS & $25.6 \times 10^{4} / \mu \mathrm{L}$ \\
\hline \multicolumn{2}{|l|}{ Glucose } \\
\hline FBS & 86 mg/dL \\
\hline $\mathrm{HbA1c}$ & $6.1 \%$ \\
\hline \multicolumn{2}{|l|}{ Lipids } \\
\hline TC & $335 \mathrm{mg} / \mathrm{dL}$ \\
\hline $\mathrm{HDL}-\mathrm{C}$ & $45 \mathrm{mg} / \mathrm{dL}$ \\
\hline TGs & $211 \mathrm{mg} / \mathrm{dL}$ \\
\hline LDL-C & $248 \mathrm{mg} / \mathrm{dL}$ \\
\hline \multicolumn{2}{|l|}{ Thyroid } \\
\hline TSH & $>500 \mu \mathrm{lU} / \mathrm{mL}$ \\
\hline fT4 & $<0.15 \mathrm{ng} / \mathrm{dL}$ \\
\hline fT3 & $1.4 \mathrm{pg} / \mathrm{mL}$ \\
\hline Tg antibody & $>4000 \mathrm{IU} / \mathrm{mL}$ \\
\hline TPO antibody & $10 \mathrm{IU} / \mathrm{mL}$ \\
\hline \multicolumn{2}{|l|}{ Biochemistry } \\
\hline TP & $6.9 \mathrm{~g} / \mathrm{dL}$ \\
\hline TB & $0.8 \mathrm{mg} / \mathrm{dL}$ \\
\hline AST & $57 \mathrm{U} / \mathrm{L}$ \\
\hline ALT & $49 \mathrm{U} / \mathrm{L}$ \\
\hline LDH & $353 \mathrm{U} / \mathrm{L}$ \\
\hline ALP & $209 \mathrm{U} / \mathrm{L}$ \\
\hline YGTP & $75 \mathrm{U} / \mathrm{L}$ \\
\hline CK & $1581 \mathrm{U} / \mathrm{L}$ \\
\hline $\mathrm{Cr}$ & $1.46 \mathrm{mg} / \mathrm{dL}$ \\
\hline UA & $6.9 \mathrm{mg} / \mathrm{dL}$ \\
\hline BUN & $11.4 \mathrm{mg} / \mathrm{dL}$ \\
\hline $\mathrm{Na}$ & 139 mEq/L \\
\hline K & $4.1 \mathrm{mEq} / \mathrm{L}$ \\
\hline $\mathrm{Cl}$ & 98 mEq/L \\
\hline CRP & $0.17 \mathrm{mg} / \mathrm{dL}$ \\
\hline
\end{tabular}

Abnormal findings are italicized

$A L P$ alkaline phosphatase, $A L T$ alanine aminotransferase, $A S T$ aspartate aminotransferase, $B U N$ blood urea nitrogen, $C B C$ complete blood count, $C K$ creatine kinase, $\mathrm{Cl}$ chloride; $\mathrm{Cr}$ creatinine, $C R P$ C-reactive protein, $F B S$ fasting blood sugar, fT3 free triiodothyronine, fT4 free thyroxine, $\gamma$ GTP gamma-glutamyl transferase, $\mathrm{HbA} 1 \mathrm{c}$ glycated hemoglobin, $\mathrm{HDL}$-C high-density lipoprotein cholesterol, $\mathrm{Hg} b$ hemoglobin, $K$ potassium, $L D H$ lactate dehydrogenase, $L D L-C$ low-density lipoprotein cholesterol, Na sodium, PLTs platelets, RBCs red blood cells, TB total bilirubin, $T C$ total cholesterol, $T g$ thyroglobulin, $T G$ s triglycerides, $T P$ total protein, TPO thyroperoxidase, TSH thyroid-stimulating hormone, UA uric acid, WBCs white blood cells

In April 2014, the patient's body weight had decreased to $125.2 \mathrm{~kg}$, and post-CPAP polysomnography indicated improved OSA (AHI, 2.8 events/h; minimal $\mathrm{SpO}_{2}, 88 \%$ ). A monthly follow-up visit was scheduled to check his body weight and adherence to CPAP. The memory stick of the CPAP machine showed that he used CPAP for 
an average of $6 \mathrm{~h}$ per night, 6 days a week, and that he had an AHI of approximately 2.0 events/h. In the course of gradually increasing the dose of levothyroxine, the patient reportedly felt better and had recovered from his fatigue and lethargy.

To address his weight loss as a priority, an LCD was initiated in July 2014 [7]. Yamada et al. [8] reported the benefits of a non-calorie-restricted LCD with the amount of carbohydrates limited to 70-130 g/day for Japanese patients with type 2 diabetes. The patient consumed $50 \mathrm{~g}$ of white rice per meal in addition to vegetables, fish, eggs, and meat in the morning and at noon; however, he did not eat rice, noodles, or other carbohydrates at night. In February 2015, the dose of $175 \mu \mathrm{g} /$ day levothyroxine appeared to maintain a euthyroid state (TSH, $0.75 \mu \mathrm{IU} /$ $\mathrm{mL}$ ), and his other laboratory results were within normal limits, including an HbA1c level of $5.3 \%$, TC level of $194 \mathrm{mg} / \mathrm{dL}$, and TG level of $89 \mathrm{mg} / \mathrm{dL}$.

Finally, in July 2015, the patient's body weight reached $98.3 \mathrm{~kg}$, a reduction of $32.4 \mathrm{~kg}$ ( $25 \%$ of his initial body weight), while his BMI decreased from 41.0 to $30.8 \mathrm{~kg} / \mathrm{m}^{2}$. Figure 1 shows changes in his body weight and TSH level over time. The patient felt motivated by the prospect of discontinuing the CPAP therapy, and was encouraged by the consistent weight loss at the monthly clinical visits. He also wanted to continue with the LCD because he did not find it difficult.

\section{Discussion}

The course of this patient provided two important clinical suggestions. First, this obese Japanese man with OSA achieved a weight loss of $32.4 \mathrm{~kg}$ ( $25 \%$ of his initial body weight) by medical therapy alone. Second, an LCD may be an effective intervention for obese Japanese patients with OSA.

There are three potential mechanisms for this patient's successful weight loss. First, CPAP was able to control

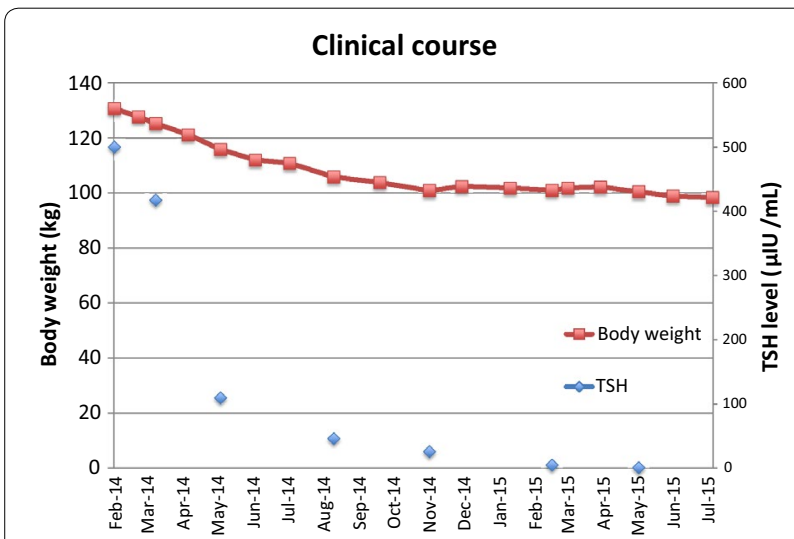

Fig. 1 Changes in the patient's body weight and thyroid-stimulating hormone (TSH) level over time his sleepiness effectively. Second, his primary hypothyroidism was corrected to a euthyroid state with $175 \mu \mathrm{g} /$ day levothyroxine. Third, an LCD was initiated as dietary therapy. Therefore, both OSA and primary hypothyroidism were treated simultaneously in this patient. He recovered from his fatigue and lethargy, thus enabling him to reduce his body weight more proactively. In developed Western countries, bariatric surgery can be performed for weight loss in patients with obesity $[1,4]$. Such surgeries have been shown to achieve a weight loss of $24.5-27.8 \mathrm{~kg}$ (20.6-24.5\% of initial body weight) after $2-3$ years $[1,4]$. Therefore, the weight loss of this patient after 2 years was similar to that observed in those who have undergone bariatric surgery.

An LCD is an effective intervention for weight loss in patients with obesity [7]. Japanese individuals typically consume a higher amount of carbohydrates compared with Western populations, obtaining approximately $60 \%$ of their total energy intake from carbohydrates [9]. Therefore, an LCD may have a superior weight loss effect in obese Japanese patients. As far as we know, this is the first case in which an LCD was initiated in an obese Japanese patient with OSA. An LCD was introduced in this case in July 2014. His weight loss from June to July was $1.4 \mathrm{~kg}$, whereas, from July to August, his weight loss was $5.1 \mathrm{~kg}$. Thus, the LCD seemed to accelerate his weight loss. His glucose and lipid metabolism also improved without diabetes or hyperlipidemia medication. In a previous large long-term observational study in Japan, a usual LCD was found to be significantly inversely associated with cardiovascular and total mortality [9]. Therefore, an LCD could allow Japanese primary care physicians to achieve clinically meaningful weight loss in their obese patients, which they might not be able to accomplish otherwise. However, because CPAP may increase the body weight of obese patients with OSA [5, $10]$, additional therapy for weight loss is required. Furthermore, weight loss after levothyroxine replacement for hypothyroidism does not always occur $[11,12]$. In a previous study, levothyroxine achieved a weight loss of only $4.3 \mathrm{~kg}$ (from an average of 83.7-79.4 kg) after 1 year [13]. Moreover, such weight loss occurred due to decrease in lean body mass, whereas fat mass did not decline [13]. This suggests that the weight loss after levothyroxine replacement was due to loss of excess body water associated with untreated myxedema [13]. Thus, levothyroxine replacement alone may not achieve an adequate weight loss in patients with hypothyroidism.

\section{Conclusion}

We described an obese Japanese man with OSA and primary hypothyroidism who achieved a weight loss of $32.4 \mathrm{~kg}$ ( $25 \%$ of his initial body weight) by medical 
therapy alone. We further demonstrated that an LCD may be an effective intervention for weight loss in obese Japanese patients with OSA. Further studies are needed to investigate the weight loss effect of an LCD compared with a conventional calorie-restricted diet. Hopefully, this case report will help to improve the management of obese Asian patients with OSA who typically consume a higher amount of carbohydrates.

\section{Abbreviations}

AHI: apnea-hypopnea index; BMI: body mass index; CPAP: continuous positive airway pressure; HbA1c: glycated hemoglobin; LCD: low-carbohydrate diet; OSA: obstructive sleep apnea; TC: total cholesterol; TGs: triglycerides.

\section{Authors' contributions}

YT managed the patient and drafted the manuscript. YN performed the thyroid ultrasonography and advised the management of the patient. YM analyzed the sleep studies and managed the CPAP at the patient's home. FT supervised both the management of the patient and the drafting of the manuscript. All authors read and approved the final manuscript.

\section{Author details}

${ }^{1}$ Tokuchi Naika Clinic, 3-6, Iwamizawa, Hokkaido 068-0023, Japan. ${ }^{2}$ Hokkaido Air Water Inc., Kikusui 5-2-3-12, Shiroishi-ku, Sapporo, Hokkaido 003-0805, Japan.

\section{Acknowledgements}

The authors wish to thank Drs. K. Ebe (Takao Hospital) and J. Kanaya (Sapporo Masui Clinic) for their helpful advice and discussion. They also wish to thank Editage (www.editage.jp) for providing its English language editing service.

\section{Competing interests}

The authors declare that they have no competing interests.

\section{Availability of data and materials}

The datasets supporting the conclusions of this article are included within the article and its additional files.

\section{Consent for publication}

Written informed consent was obtained from the patient for publication of this case report and any accompanying images.

Received: 9 June 2016 Accepted: 29 July 2016

Published online: 05 August 2016

\section{References}

1. Dixon JB, Schachter LM, O'Brien PE, Jones K, Grima M, Lambert G, et al. Surgical vs conventional therapy for weight loss treatment of obstructive sleep apnea: a randomized controlled trial. JAMA. 2012;308:1142-9.

2. Wadden TA, Volger S, Sarwer DB, Vetter ML, Tsai AG, Berkowitz RI, et al. A two-year randomized trial of obesity treatment in primary care practice. N Engl J Med. 2011;365:1969-79.

3. Kanke S, Kawai T, Takasawa N, Mashiyama Y, Ishii A, Kassai R. Interventions for body weight reduction in obese patients during short consultations: an open-label randomized controlled trial in the Japanese primary care setting. Asia Pac Fam Med. 2015:14:5.

4. Schauer PR, Bhatt DL, Kirwan JP, Wolski K, Brethauer SA, Navaneethan SD, et al. Bariatric surgery versus intensive medical therapy for diabetes3-year outcomes. N Engl J Med. 2014;370:2002-13.

5. Drager LF, Brunoni AR, Jenner R, Lorenzi-Filho $G$, Benseñor IM, Lotufo PA. Effects of CPAP on body weight in patients with obstructive sleep apnoea: a meta-analysis of randomised trials. Thorax. 2015;70:258-64.

6. Attal P, Chanson P. Endocrine aspects of obstructive sleep apnea. J Clin Endocrinol Metab. 2010;95:483-95.

7. Shai I, Schwarzfuchs D, Henkin Y, Shahar DR, Witkow S, Greenberg I, et al. Weight loss with a low-carbohydrate, Mediterranean, or low-fat diet. N Engl J Med. 2008:359:229-41.

8. Yamada Y, Uchida J, Izumi H, Tsukamoto Y, Inoue G, Watanabe Y, et al. A non-calorie-restricted low-carbohydrate diet is effective as an alternative therapy for patients with type 2 diabetes. Intern Med. 2014;53:13-9.

9. Nakamura Y, Okuda N, Okamura T, Kadota A, Miyagawa N, Hayakawa T, et al. Low-carbohydrate diets and cardiovascular and total mortality in Japanese: a 29-year follow-up of NIPPON DATA80. Br J Nutr. 2014:112:916-24.

10. Tachikawa R, Ikeda K, Minami T, Matsumoto T, Hamada S, Murase K, et al. Changes in energy metabolism after continuous positive airway pressure for obstructive sleep apnea. Am J Respir Crit Care Med. 2016 Mar 1. [Epub ahead of print].

11. Lee SY, Braverman LE, Pearce EN. Changes in body weight after treatment of primary hypothyroidism with levothyroxine. Endocr Pract. 2014;20:1122-8.

12. Skjodt NM, Atkar R, Easton PA. Screening for hypothyroidism in sleep apnea. Am J Respir Crit Care Med. 1999;160:732-5.

13. Karmisholt J, Andersen S, Laurberg P. Weight loss after therapy of hypothyroidism is mainly caused by excretion of excess body water associated with myxoedema. J Clin Endocrinol Metab. 2011;96:E99-103.

Submit your next manuscript to BioMed Central and we will help you at every step:

- We accept pre-submission inquiries

- Our selector tool helps you to find the most relevant journal

- We provide round the clock customer support

- Convenient online submission

- Thorough peer review

- Inclusion in PubMed and all major indexing services

- Maximum visibility for your research

Submit your manuscript at www.biomedcentral.com/submit 